\title{
Interactive comment on "High organic carbon burial but high potential for methane ebullition in the sediments of an Amazonian reservoir" by Gabrielle R. Quadra et al.
}

Gabrielle R. Quadra et al.

gabrielle.quadra@ecologia.ufjf.br

Received and published: 6 September 2019

Dear Maciej Bartosiewicz,

Thank you for your comments and suggestions, which were very constructive and helpful to improve our manuscript. We address all the comments, point-by-point, in the supplement.

Kind regards, Gabrielle Quadra on behalf of the authors.

Please also note the supplement to this comment: 
https://www.biogeosciences-discuss.net/bg-2019-246/bg-2019-246-AC1supplement.pdf

Interactive comment on Biogeosciences Discuss., https://doi.org/10.5194/bg-2019-246, 2019. 